\title{
Characterization of Renibacterium salmoninarum with reduced susceptibility to macrolide antibiotics by a standardized antibiotic susceptibility test
}

\author{
Linda D. Rhodes ${ }^{1, *}$, Oanh T. Nguyen ${ }^{1}$, Rebecca K. Deinhard ${ }^{2}$, Teresa M. White ${ }^{3}$, \\ Lee W. Harrell ${ }^{1}$, Marilyn C. Roberts ${ }^{3}$ \\ ${ }^{1}$ Northwest Fisheries Science Center, National Marine Fisheries Service, 2725 Montlake Blvd. East, Seattle, \\ Washington 98112, USA \\ ${ }^{2}$ Pacific States Marine Fisheries Commission, 205 SE Spokane Street, Suite 100, Portland, Oregon 97202, USA \\ ${ }^{3}$ Department of Environmental \& Occupational Health Sciences, Box 357234, School of Public Health and Community \\ Medicine, University of Washington, Seattle, Washington 98195, USA
}

\begin{abstract}
Three cohorts of juvenile and subadult Chinook salmon Oncorhynchus tshawytscha received multiple treatments with macrolide antibiotics for bacterial kidney disease (BKD) during rearing in a captive broodstock program. A total of 77 mortalities among the cohorts were screened for Renibacterium salmoninarum, the etiologic agent of BKD, by agar culture from kidney, and isolates from 7 fish were suitable for growth testing in the presence of macrolide antibiotics. The minimum inhibitory concentration (MIC) of erythromycin and azithromycin was determined by a modification of the standardized broth assay using defined medium. The American Type Culture Collection (ATCC) type strain 33209 exhibited a MIC of $0.008 \mu \mathrm{g} \mathrm{ml}^{-1}$ to either erythromycin or azithromycin. Isolates from 3 fish displayed MICs identical to the MICs for the ATCC type strain 33209. In contrast, isolates from 4 fish exhibited higher MICs, ranging between 0.125 and $0.250 \mu \mathrm{g} \mathrm{ml}^{-1}$ for erythromycin and between 0.016 and $0.031 \mathrm{\mu g} \mathrm{ml}^{-1}$ for azithromycin. Sequence analysis of the mutational hotspots for macrolide resistance in the 23S rDNA gene and the open reading frames of ribosomal proteins L4 and L22 found identical sequences among all isolates, indicating that the phenotype was not due to mutations associated with the drug-binding site of 23S rRNA. These results are the first report of $R$. salmoninarum with reduced susceptibility to macrolide antibiotics isolated from fish receiving multiple antibiotic treatments.
\end{abstract}

KEY WORDS: Antimicrobial agent susceptibility testing · Macrolide antibiotic · Reduced susceptibility · Renibacterium salmoninarum • Bacterial kidney disease

\section{INTRODUCTION}

Salmon and trout are among the most intensively cultured fish for both direct harvest and for release into the natural environment. In the northwestern part of the continental USA, Pacific salmon species are reared by governments, tribes, and private organizations for supplementation or restoration of natural runs of salmon, and there are captive broodstock programs for highly endangered populations (Flagg \& Mahnaken
1995, Arkush \& Siri 2001). One of the most persistent diseases observed among cultured salmon is bacterial kidney disease (BKD), which is caused by the Grampositive microorganism Renibacterium salmoninarum. While acute BKD can cause high mortality among juvenile fish prior to release from rearing facilities, it is possible that most infected juveniles are asymptomatic. $R$. salmoninarum can be transmitted horizontally among cohabiting fish as well as vertically through intraovum transfer, and fish may be suscep- 
tible to infection throughout the entire life cycle. For fish culturists, the windows of opportunity to deliver therapeutics against BKD are limited, and antibiotics are the most commonly used agents.

By 1990, erythromycin was demonstrated to be potentially effective against vertical transmission of Renibacterium salmoninarum (Bullock \& Leek 1986, Evelyn et al. 1986, Brown et al. 1990), and injection of female broodstock with erythromycin is currently a routine procedure in many US rearing facilities (e.g. Washington Department of Fish and Wildlife 2002, US Fish and Wildlife Service 2005). In the US, erythromycin may be used in food salmonids under an Investigational New Animal Drug (INAD) application, although approval is still pending (National Coordinator for Aquaculture New Animal Drug Applications 2007). In captive broodstock programs for endangered stocks of salmon, a percentage of fish are held through the entire life cycle, and the risk of BKD epidemics can be high. In those programs oral or injected macrolides may be administered anytime during growth to maturity.

Azithromycin, a semi-synthetic derivative of erythromycin, has a broader spectrum of activity against bacteria than erythromycin, and it is active against Grampositive bacteria, Mycobacterium avium-intracellulare, and some Gram-negative species (Ballow \& Amsden 1992, Kirst 2002). Unlike erythromycin, azithromycin may not be administered to food fish. In Chinook salmon, azithromycin accumulates to higher levels and is eliminated more slowly than erythromycin (Fairgrieve et al. 2006), a pattern that is consistent with the pharmacokinetics observed in mammalian cells for this antibiotic (Peters et al. 1992, Bosnar et al. 2005). Furthermore, azithromycin is transferred from injected female broodstock to offspring and persists up to $70 \mathrm{~d}$ after the start of exogenous feeding (Fairgrieve et al. 2006).

Since the Swann report in 1969 in the UK (Swann 1969), there has been concern about the contribution of agricultural use antibiotics to generating drug-resistant bacterial strains that cause disease in both man and food animals (Shea et al. 2004, Gilchrist et al. 2007). The potential for selecting Renibacterium salmoninarum isolates with reduced susceptibility to erythromycin was documented approximately 20 yr ago when Bell et al. (1988) generated an isolate with reduced susceptibility to erythromycin by successive growth of the isolate in increasing concentrations of erythromycin in broth culture. The authors did not determine the underlying mechanisms, but they did demonstrate that $R$. salmoninarum was capable of developing resistance to erythromycin under intense selective pressure. Because macrolides are widely administered to cultured salmonids in the US to treat
$\mathrm{BKD}$, it is important to determine whether $R$. salmoninarum with altered drug susceptibility can arise in treated fish. As an initial assessment, we screened a population of captive broodstock Chinook salmon that had received multiple treatments with macrolide antibiotics for BKD. In order to assess the level of susceptibility to antibiotics, a standardized susceptibility test was developed.

\section{MATERIALS AND METHODS}

Fish culture and treatments. Oncorhynchus tshawytscha were collected as parr from natal streams in the Grande Ronde Basin by the Oregon Department of Fish and Game in August of 2003, 2004, and 2005, and cohorts were identified as BY02, BY03, and BY04, respectively (Table 1). Fish were collected and reared under provisions of the US Endangered Species Act, and their care and welfare was monitored by a Technical Oversight Team. Fish were reared in first-passage well water until smoltification approximately 9 mo after collection, and then transferred to filtered (to $5 \mu \mathrm{m})$, ultraviolet light-treated, single-passage seawater. Fish were fed at an initial rate of $2.5 \%$ of body weight $\mathrm{d}^{-1}$ with Nutra Fry (Skretting), and the rate was tapered to a final adult rate of $1 \%$ of body weight $\mathrm{d}^{-1}$ with Vitalis Salmon Brood (Skretting).

Within $7 \mathrm{~d}$ of collection, all fish received an intraperitoneal injection of azithromycin (Zithromax; Pfizer) at a dose of $20 \mathrm{mg} \mathrm{kg}^{-1}$ body weight. Subsequently, when mortality due to clinical BKD occurred, all fish in a cohort were treated with erythromycin by injection $(20$ or $40 \mathrm{mg} \mathrm{kg}^{-1}$ body weight) or by feeding (100 $\mathrm{mg} \mathrm{kg}^{-1}$ body weight) (Table 1). Injected erythromycin was Osborn Gallimycin 200 (Bimeda) delivered by intraperitoneal administration. Orally administered erythromycin was delivered by custom formulation of feed with Gallimycin R PFC (Bimeda) to a final concentration of $50 \mathrm{mg}$ erythromycin phosphate $\mathrm{g}^{-1}$ feed.

Isolate collection. All spontaneous mortalities were necropsied, and kidney tissue was aseptically probed and struck onto modified selective KDM2 (SKDM2) agar plates $(1 \%$ Bacto-peptone $\mathrm{w} / \mathrm{v}, 0.05 \%$ yeast extract $\mathrm{w} / \mathrm{v}, 0.05 \%$ L-cysteine $\mathrm{w} / \mathrm{v}, 10 \%$ newborn calf serum v/v [Gibco/BRL], $5 \%$ nurse medium v/v, $1.2 \%$ agar $\mathrm{w} / \mathrm{v}$; adjusted to $\mathrm{pH}$ 7.5) (Austin et al. 1983) and modified SKDM2 agar plates supplemented with $0.0125 \mu \mathrm{g} \mathrm{ml}^{-1}$ azithromycin. Agar plates with azithromycin were used to enrich for bacteria with altered drug susceptibility, whereas agar plates without azithromycin were used to confirm that isolates originated from fish, not by in vitro selection. Isolates were transferred to basal KDM broth (1\% Bacto-peptone $\mathrm{w} / \mathrm{v}, 0.05 \%$ yeast extract $\mathrm{w} / \mathrm{v}, 0.05 \%$ L-cysteine $\mathrm{w} / \mathrm{v}$; 
Table 1. Oncorhynchus tshawytscha. Date (including date of transfer to seawater), mode, dose, and duration of macrolide treatment. -: no antibiotic treatment

\begin{tabular}{|c|c|c|c|c|c|}
\hline $\begin{array}{l}\text { Broodyear } \\
\text { cohort }\end{array}$ & $\begin{array}{c}\text { Treatment } \\
\text { date (mo/yr) }\end{array}$ & Macrolide & $\begin{array}{l}\text { Mode of } \\
\text { treatment }\end{array}$ & $\begin{array}{l}\text { Dose (mg kg-1 } \\
\text { body weight) }\end{array}$ & $\begin{array}{l}\text { Duration of } \\
\text { treatment }(d)\end{array}$ \\
\hline \multirow[t]{11}{*}{ BY02 } & $8 / 03$ & Azithromycin & Injection & 20 & 1 \\
\hline & $4 / 04$ & Azithromycin & Injection & 20 & 1 \\
\hline & $5 / 04$ & - & Transfer to seawater & - & - \\
\hline & $6 / 04$ & Erythromycin & Oral & 100 & 28 \\
\hline & $10 / 04-11 / 04$ & Erythromycin & Oral & 100 & 21 \\
\hline & $11 / 04$ & Erythromycin & Injection & 40 & 1 \\
\hline & $12 / 04$ & Erythromycin & Injection & 40 & 1 \\
\hline & $3 / 05$ & Erythromycin & Injection & 40 & 1 \\
\hline & $4 / 05$ & Erythromycin & Injection & 20 & 1 \\
\hline & $4 / 05-5 / 05$ & Erythromycin & Oral & 100 & 29 \\
\hline & $5 / 05$ & Erythromycin & Injection & 40 & 1 \\
\hline \multirow[t]{4}{*}{ BY03 } & $8 / 04$ & Azithromycin & Injection & 20 & 1 \\
\hline & $5 / 05$ & - & Transfer to seawater & - & - \\
\hline & $6 / 05$ & Erythromycin & Oral & 100 & 29 \\
\hline & $7 / 05$ & Erythromycin & Injection & 40 & 1 \\
\hline \multirow[t]{2}{*}{ BY04 } & $8 / 05$ & Azithromycin & Injection & 20 & 1 \\
\hline & $5 / 06$ & - & Transfer to seawater & - & - \\
\hline
\end{tabular}

adjusted to $\mathrm{pH}$ 7.5). If the originating plate did not contain azithromycin, no azithromycin was added to the broth. If the originating plate contained azithromycin, azithromycin was added to a final concentration $0.0125 \mu \mathrm{g} \mathrm{ml} \mathrm{m}^{-1}$. Culture purity was ascertained by Gram stain morphology and by epifluorescence microscopy using an anti- $R$. salmoninarum polyclonal antibody (Kirkegaard and Perry).

Generation time determination. Broth cultures were established in basal KDM at an optical density at $\mathrm{OD}_{525}$ $\mathrm{nm}$ between 0.05 and 0.1 (which is approximately 1 to $2 \times 10^{8}$ bacterial cells) by the membrane filtration technique, a method to directly enumerate bacterial cells by antibody-mediated fluorescence microscopy (Elliott \& Barila 1987). ODs were read at $525 \mathrm{~nm}$ for tube cultures and at $595 \mathrm{~nm}$ for microplate cultures. Measurements were taken at the beginning (time 0 ) and approximately every $24 \mathrm{~h}$ for 72 to $96 \mathrm{~h}$ to ensure that only log phase growth was included for generation time calculations.

Minimum inhibitory concentration (MIC) testing. MIC assays using 2 different culture volumes were tested. A larger volume test (10 ml starting volume) was performed in glass tubes, and a smaller volume test $(200 \mu \mathrm{l})$ was performed in 96-well microplates. Both assays used basal KDM broth with incubation at $15^{\circ} \mathrm{C}$ and agitation at $150 \mathrm{rpm}$. For each strain, a culture containing no antibiotic was included in each assay. In addition, a Renibacterium salmoninarum strain with high susceptibility (American Type Culture Collection, ATCC, type strain 33209) was in- cluded for comparison within assays. Cultures for both tests were grown to an $\mathrm{OD}_{525}$ range of 0.8 to 1.0 immediately prior to testing. Erythromycin (Sigma) was dissolved in $30 \%$ ethyl alcohol to a stock concentration of $10 \mathrm{mg} \mathrm{ml}^{-1}$, and azithromycin (Zithromax; Pfizer) was dissolved in sterile distilled water to a stock concentration of $125 \mathrm{mg} \mathrm{ml}^{-1}$. Serial dilutions of erythromycin and azithromycin for testing were made from the stocks with sterile distilled water immediately prior to use (Clinical and Laboratory Standards Institute 2006). Each isolate was tested at lower passage number (Passage 2 or 3 ) and at higher passage number (Passage 9 or 10). The concentration of antibiotic that produced a detectable reduction in growth was defined as the MIC (Clinical and Laboratory Standards Institute 2006).

In the tube MIC assays, bacterial growth was assayed in serial 2-fold dilutions of antibiotic ranging from 0.004 to $2 \mu \mathrm{g} \mathrm{ml}^{-1}$ in KDM2 broth to a total volume of $10 \mathrm{ml}$. Bacterial cultures at all drug concentrations were established at an $\mathrm{OD}_{525}$ range of 0.05 to 0.10 (approximately 1 to $2 \times 10^{8}$ bacterial cells). All $\mathrm{OD}_{525}$ measurements were performed in polystyrene cuvettes with a $10 \mathrm{~mm}$ light path (Fisher Scientific) using a 2-position UV-visible recording spectrophotometer (Shimadzu). Measurements were taken at the start of the assay (time 0) and approximately every $24 \mathrm{~h}$ up to $4 \mathrm{~d}$.

In the microplate MIC assays, culture growth was assayed in serial 2-fold dilutions of drugs ranging from 0.0125 to $0.20 \mu \mathrm{g} \mathrm{ml}^{-1}$ in basal KDM broth using 
$200 \mu \mathrm{l}$ per well. For each drug dilution, bacterial cell concentrations were established at four 2-fold dilutions with an $\mathrm{OD}_{525} \mathrm{~nm}$ range of 0.0125 to 0.1. Each bacterial and drug concentration test was performed in duplicate. Cultures were established in sterile, polystyrene, flat-bottomed 96-well tissue culture plates (Costar). Prior to $\mathrm{OD}_{525}$ reading, the wells were mixed by gentle pipette action to thoroughly resuspend bacterial cells. Measurements were taken at the start of the assay (time 0 ) and approximately every $24 \mathrm{~h}$ up to $4 \mathrm{~d}$.

Sequencing 23S rDNA and ribosomal proteins L4 and L22. Bacteria were grown in basal KDM broth and chromosomal DNA isolated as previously reported (Rhodes et al. 2000). Target sites were amplified from chromosomal DNA with the primers (Operon) specified in Table 2 using high fidelity Vent (exo-) DNA polymerase (New England Biolabs). Amplicons were purified by silica spin column (MoBio) and subjected to sequencing using BigDye terminator mix v3.1 and analyzed with an ABI3100 (Applied Biosystems). DNA sequences from fishderived isolates were compared to those from the type strain ATCC 33209. There are 2 copies of the 23S rRNA genes in Renibacterium salmoninarum (Grayson et al. 2000). Because the 23S rDNA sequence is identical for at least $5 \mathrm{~kb}$ around the sequencing target site, one primer pair amplified both copies of the 23S rDNA, and the sequences were examined for heterozygosity.

Kidney BKD enzyme-linked immunosorbent assay (BKD ELISA) and antibiotic activity assay. Kidney samples were collected and analyzed for bacterial antigen levels with a polyclonal anti-Renibacterium salmoninarum antibody following the method of Pascho \& Mulcahy (1987). Kidney tissue was analyzed for residual antibiotic activity by the method of Fairgrieve et al. (2006).

\section{RESULTS}

\section{Isolate frequency, generation time of isolates, and kidney tissue assays}

A total of 77 fish that were treated with macrolide antibiotics were screened by culture for Renibacterium salmoninarum; 10 fish were from the BY02 cohort, 56 fish were from the BY03 cohort and 11 fish from the BY04 cohort. $R$. salmoninarum isolates suitable for testing were obtained from 7 fish, and all 7 fish were from the BY02 cohort. Six isolates were derived on agar plates without azithromycin supplementation, and 2 isolates were derived on plates with azithromycin supplementation. For one fish (05-372), testable isolates were derived from both the modified SKDM2 plate (05-372 K) and on the modified SKDM2 plate supplemented with azithromycin (05-372 A).

The average generation time ranged from an average of $24.5 \mathrm{~h}$ (range 24.2 to $25.0 \mathrm{~h}$ ) for isolate 06-383 to an average of $34.2 \mathrm{~h}$ (range 25.9 to $41.9 \mathrm{~h}$ ) for isolate $05-372 \mathrm{~K}$ (Fig. 1). However, there was no significant difference in generation time among the isolates (ANOVA, $p=0.092$ ). Analysis of kidney tissue for bacterial antigen levels showed that all source fish producing testable isolates had clinical BKD at death (Fig. 2). Most of the fish that did not produce testable isolates (51 of 68 fish) exhibited a low BKD ELISA value, indicating these fish had no infection or low-grade infections (Fig. 2). Kidney tissue for antibiotic activity analysis was available for 59 of the 77 fish. Detectable levels of macrolide activity were found in only 4 fish and ranged from 0.68 to $1.00 \mu \mathrm{g}$ equivalents of azithromycin activity $\mathrm{g}^{-1}$ tissue (data not shown). Tissue antibiotic activity was available for 2 of the 7 fish that produced isolates for testing (05-334 and 05-882), and there was no detectable activity in either kidney sample.

Table 2. Primers used for PCR amplification from chromosomal DNA and amplicon sequencing

\begin{tabular}{|llcc|}
\hline Primer name & Sequence (5' to 3') & Target gene & Application \\
\hline Rsal23SrRNA1F & CATCGACGCGAGGTTCCAGCCGCCCGT & 23S ribosomal DNA & Amplification, sequencing \\
Rsal 23SrRNA2R & GCCAAACCATGCCGTCGATATGGACTC & 23S ribosomal DNA & Amplification, sequencing \\
Rsal 23SrRNA3F & GTAGCGAAATTCCTTGTCGG & 23S ribosomal DNA & Sequencing \\
Rsal 23SrRNA4R & GGTATTTCAACGATGACTCCA & 23S ribosomal DNA & Sequencing \\
RsalL4F1 & GAGAACGTCACACCACGTTGAACCT & Ribosomal protein L4 & Amplification \\
RsalL4R2 & CTTGATCTCGGTCTTGTTCGAGCGC & Ribosomal protein L4 & Amplification \\
RsalL4F3 & GTCCCTGCTGCTCATCAAG & Ribosomal protein L4 & Sequencing \\
RsalL4R4 & GTCGATTAGGCCGTAGCTC & Ribosomal protein L4 & Sequencing \\
RsalL22F1 & GGTGTTCGTGACCGAGTCGATGGTC & Ribosomal protein L22 & Amplification \\
RsalL22R2 & CGATTTCAACCTTGGCAATGCCAGC & Ribosomal protein L22 & Amplification \\
RsalL22F3 & TGTGAAGGACGACCGTAAG & Ribosomal protein L22 & Sequencing \\
RsalL22R4 & TGCCCGTAGACATGAGTTG & Ribosomal protein L22 & Sequencing \\
\hline
\end{tabular}




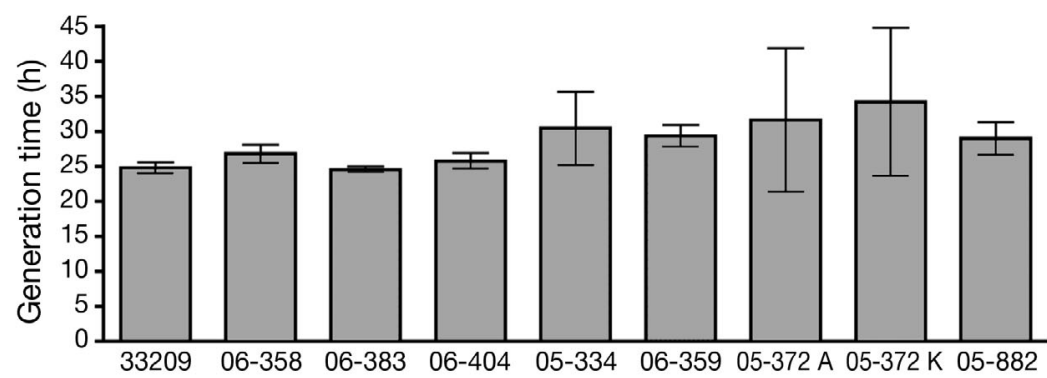

Fig. 1. Renibacterium salmoninarum. Average generation time ( \pm range) for ATCC type strain 33209 and for 8 isolates from treated fish for at least 2 replicated experiments assay (Table 3). The correlation between the MICs was not perfect (Spearman's rho $=0.750, \mathrm{p}=0.066)$, and values for 2 of the 7 tested isolates did not agree (Table 3). Generation time in the microplate assays was approximately twice as long as the corresponding generation time in the tube assays (Fig. 3), and maximum optical density readings in the microplate assays were below 0.8 (data not shown), indicating that the cultures were not under optimal in vitro conditions for growth.

\section{MICs of macrolides}

In the standardized tube assay, the ATCC 33209 strain exhibited high susceptibility to both erythromycin and azithromycin, with a MIC value of $0.008 \mu \mathrm{g}$ $\mathrm{ml}^{-1}$ for each drug (Table 3), and isolates 06-358, 06-383, and 06-404 displayed identical MICs (Table 3). In contrast, 5 isolates (05-334, 06-359, 05-372 A, 05-372 $\mathrm{K}$, and 05-882) exhibited erythromycin MICs that were 15 to 30 times higher than that for ATCC 33209, ranging between 0.125 and $0.250 \mu \mathrm{g} \mathrm{ml}^{-1}$ (Table 3). These same isolates also displayed higher MICs to azithromycin than ATCC 33209, ranging between 0.016 and $0.031 \mu \mathrm{g} \mathrm{ml}^{-1}$. Among the isolates with reduced susceptibility, there was no correlation between erythromycin and azithromycin MICs (Spearman rho $=-0.67$, $\mathrm{p}=0.233$ ).

To assess the utility of the microplate assay, azithromycin MIC values obtained by the microplate assay were compared to those obtained by the tube

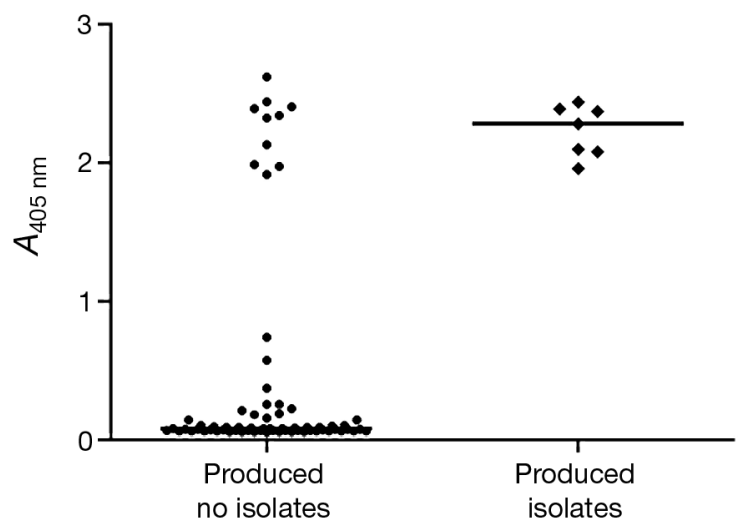

Fig. 2. Oncorhynchus tshawytscha. Bacterial kidney disease enzyme-linked immunosorbent assay (BKD ELISA) values of fish screened by culture, comparing fish that produced testable Renibacterium salmoninarum isolates (produced isolates) with those that failed to produce isolates (produced no isolates). $A_{405 \mathrm{~nm}}$ : absorbance at $405 \mathrm{~nm}$. Horizontal line: median absorbance

\section{S rDNA sequences and ribosomal proteins L4 and L22 sequences}

A 924 bp region of the 23S rDNA that encompasses the known mutational hotspot for macrolide resistance was amplified by high fidelity PCR, sequenced, and examined for heterozygosity. There was no difference in sequence throughout this region between ATCC 33209 and all of the isolates.

To determine whether there were mutations in the ribosomal proteins L4 and L22, the entire open reading frames for these genes were amplified and sequenced using primers positioned in the flanking non-coding regions. Again, sequences from all isolates were identical to those for ATCC 33209.

\section{DISCUSSION}

Erythromycin is widely used to treat BKD in hatcheries and broodstock rearing programs to attempt to reduce vertical transmission of Renibacterium salmoninarum to progeny. The selection of erythromycin over

Table 3. Renibacterium salmoninarum. Minimum inhibitory concentration (MIC) values for macrolide antibiotics based on tube and microplate assays. ND: test not done

\begin{tabular}{|c|c|c|c|}
\hline \multirow[t]{2}{*}{ Isolate } & \multicolumn{2}{|c|}{${ }_{\text {Tube }}-$} & \multirow{2}{*}{$\begin{array}{c}\text { Microplate } \\
\text { Azithromycin } \\
\text { MIC }\left(\mu g \mathrm{ml}^{-1}\right)\end{array}$} \\
\hline & Erythromycin & Azithromycin & \\
\hline ATCC 33209 & 0.008 & 0.008 & 0.008 \\
\hline $05-334$ & 0.125 & 0.031 & 0.016 \\
\hline $06-358$ & 0.008 & ND & 0.008 \\
\hline $06-359$ & 0.125 & 0.031 & 0.031 \\
\hline $05-372 \mathrm{~A}$ & 0.250 & 0.016 & 0.016 \\
\hline $05-372 \mathrm{~K}$ & 0.250 & 0.016 & 0.031 \\
\hline $06-383$ & 0.008 & 0.008 & 0.008 \\
\hline 06-404 & 0.008 & ND & 0.008 \\
\hline 05-882 & 0.250 & 0.031 & 0.031 \\
\hline
\end{tabular}




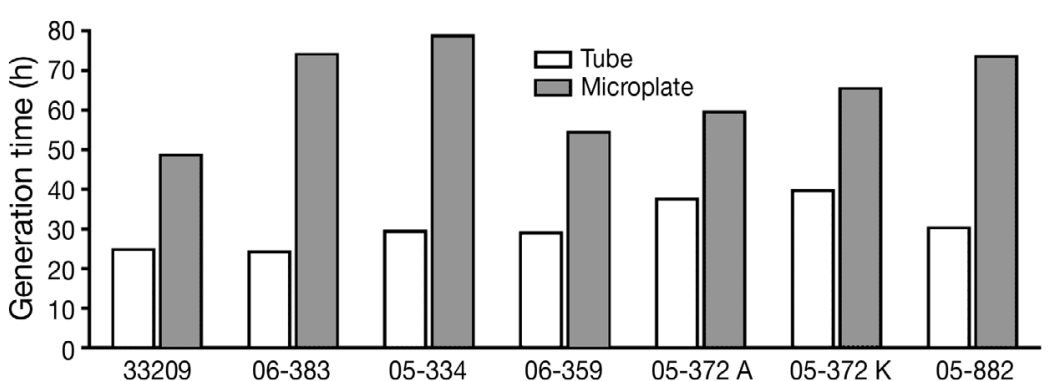

Fig. 3. Renibacterium salmoninarum. Comparison of generation times for ATCC type strain 33209 and for 6 isolates from treated fish obtained from the tube assay and the microplate assay for azithromycin

currently approved antibiotics for use in salmon aquaculture (oxytetracycline and sulfadimethoxine/ ormetoprim) appears to be based on longer persistence in progeny and greater pharmacological activity against Gram-positive bacteria (Evelyn et al. 1986, Brown et al. 1990). Concern about the selection of bacteria with decreased susceptibility to erythromycin and the proof-ofprinciple using in vitro selection was demonstrated nearly 20 yr ago (Bell et al. 1988). We isolated $R$. salmoninarum with reduced susceptibility to erythromycin and azithromycin from treated fish, demonstrating that reduced macrolide susceptibility can occur under conditions of repeated drug administration. These isolates are described as having reduced susceptibility, rather than resistant, because the MICs are much lower than those observed for resistant human or animal pathogens, with MICs ranging from $0.5 \mathrm{\mu g} \mathrm{ml}^{-1}$ to greater than $16 \mu \mathrm{g} \mathrm{ml}^{-1}$ (Hyde et al. 2001).

Previous antibiotic susceptibility tests of Renibacterium salmoninarum have reported wide variations in results. A test of $40 R$. salmoninarum isolates, including ATCC 33209, with 5 different erythromycin formulations on KDM2 agar plates found the highest susceptibility to erythromycin stearate at $0.01 \mu \mathrm{g} \mathrm{ml}^{-1}$ (Austin et al. 1983). A separate study of ATCC 33209 reported an erythromycin MIC of $0.1 \mathrm{\mu g} \mathrm{ml}^{-1}$ and an azithromycin MIC of $0.05 \mathrm{\mu g} \mathrm{ml}^{-1}$, but the media used was slightly acidic ( $\mathrm{pH}$ 6.8) and it included $10 \%$ horse serum (Gutenberger et al. 1989). It is known that erythromycin potency declines with $\mathrm{pH}$ (Sabath et al. 1968, Toala et al. 1970), and ingredients with high chemical variability such as horse serum can unpredictably affect MICs (Jones \& Barry 1987, Reinert et al. 2003). A third assessment of erythromycin susceptibility for $11 R$. salmoninarum isolates (including ATCC 33209) reported inhibitory concentrations that ranged from 0.62 to $5.47 \mathrm{\mu g} \mathrm{ml}^{-1}$ (Bandín et al. 1991). However, that study did not test concentrations lower than $0.62 \mu \mathrm{g} \mathrm{ml}^{-1}$, and the endpoint was defined as the concentration that completely inhibited growth, rather than the accepted definition of MIC. These disparate results emphasize the importance of utilizing a defined medium and a standardized protocol for performing antibiotic susceptibility testing.

The method and criteria we employed are consistent with standardized CLSI protocols (Clinical and Laboratory Standards Institute 2006), with temperature and timing modifications that are necessary for the optimal growth of Renibacterium salmoninarum. The protocol for the tube assay permits a culture without antibiotic to achieve stationary growth by the ending time point ( 72 to $96 \mathrm{~h}$ ), with a generation time of 24 to $36 \mathrm{~h}$. Although we attempted to develop a microplate assay protocol, the small volume culture conditions were not optimal for $R$. salmoninarum growth, resulting in much longer generation times (48 to $75 \mathrm{~h}$ ). Therefore, the tube assay protocol is the recommended method for MIC testing.

Macrolide resistance can arise through several mechanisms. Many resistances are due to acquisition of genes encoding new enzymes and/or proteins, and these genes are usually associated with mobile elements that can be readily transferred between unrelated genera. Because we did not search for newly acquired genes among our isolates, this is a formal possibility for the observed phenotypes. Modification of the macrolide target site can occur through methylation of 23S ribosomal RNA (erm methylases), by mutation of 23S ribosomal DNA positions A2058 or A2059 (E. coli numbering), or by mutation of ribosomal proteins L4 or L22 that interact with the target site (Gaynor \& Mankin 2003, Franceschi et al. 2004, Roberts \& Sutcliffe 2005). Although no homologues to erm family genes have been found in the Renibacterium salmoninarum genome (M. Strom pers. comm.; GenBank accession CP000910), methylation might occur through unrelated methylases. Resistance due to mutations has been found in 1 to $4 \%$ of isolates that do not carry known acquired macrolide resistance genes, including a variety of Gram-positive bacteria (Roberts \& Sutcliffe 2005). However, we observed no evidence for mutations in the 23S rDNA target site or in the L4 and L22 genes of any of the $R$. salmoninarum isolates. Methylation of rRNA or mutation of rRNA, L4, or L22 genes tend to confer a high level of resistance, with MICs for erythromycin often exceeding $16 \mu \mathrm{g} \mathrm{ml}^{-1}$ in Gram-positive bacteria such as Streptococcus pneumoniae (Reinert et al. 2003, Calatayud et al. 2007). However, the largest observed MIC for erythromycin in $R$. salmoninarum was $0.25 \mu \mathrm{g} \mathrm{ml}^{-1}$. Taken together, these findings suggest that alterations of the macrolide target site or interacting proteins are not responsible for the observed phenotype. 
The observation that only 4 of 59 fish had detectable drug activity in the kidney was not surprising. Erythromycin has a relatively short half-life in Chinook salmon, whether administered orally or by intraperitoneal injection. Orally administered erythromycin is not detectable in juvenile Chinook salmon muscle tissue by 10 d after treatment (Moffitt \& Schreck 1988) or in whole body extracts of juvenile Chinook salmon by $21 \mathrm{~d}$ after administration (Fairgrieve et al. 2005). In subadult Chinook salmon, no erythromycin can be detected in kidney, a target tissue for accumulation, by $92 \mathrm{~d}$ after injection (authors' pers. obs.). Recently, risk assessment of erythromycin in trout muscle provided evidence for a reduction in withdrawal time to 255 degree-days (i.e. $25.5 \mathrm{~d}$ at $10^{\circ} \mathrm{C}$ ) for fish for human consumption (Esposito et al. 2007). Because R. salmoninarum has a slow generation time of approximately $24 \mathrm{~h}$, it is possible that this bacterium can survive high drug levels in tissues, especially for drugs with relatively rapid elimination kinetics.

In summary, we have isolated Renibacterium salmoninarum with reduced susceptibility to erythromycin and azithromycin from fish that received multiple macrolide treatment. A standardized protocol for drug susceptibility testing in a broth assay was developed to characterize the isolates. While the MICs were not sufficiently elevated to consider these isolates drug resistant, the reduced susceptibility phenotype did not require the continuous presence of drug and may represent an intermediate step toward drug resistance. These results demonstrate that $R$. salmoninarum with reduced susceptibility to macrolides can arise in vivo.

Acknowledgements. Kidney ELISA values were provided by S. Onjukka (Oregon Department of Fish and Game), and C. K. Rathbone (Pacific States Marine Fisheries Commission) assisted in tissue antibiotic assays. Fish were cultured by W. McAuley, D. Frost (NOAA Fisheries), and B. Kluver (Pacific States Marine Fisheries Commission). Funding support provided by Bonneville Power Administration (project \# 1993056-00), NOAA Fisheries (US Department of Commerce), and the University of Washington-Howard Hughes Integrative Biology Research Internship Program. Mention of trade names or commercial products in the paper is solely for the purpose of providing specific information and does not imply recommendation or endorsement.

\section{LITERATURE CITED}

Arkush KD, Siri PA (2001) Exploring the role of captive broodstock programs in salmon restoration. Fish Bull 179: 319-329. Also available at: www.dfg.ca.gov/fish/ Resources/Reports/Bulletin179_V2.asp

Austin B, Embley TM, Goodfellow M (1983) Selective isolation of Renibacterium salmoninarum. FEMS Microbiol Lett 17:111-114

Ballow CH, Amsden GW (1992) Azithromycin: the first azalide antibiotic. Ann Pharmacother 26:1253-1261
Bandín I, Santos Y, Toranzo AE, Barja JL (1991) MICs and MBCs of chemotherapeutic agents against Renibacterium salmoninarum. Antimicrob Agents Chemother 35: 1011-1013

Bell GR, Traxler GS, Dworschak C (1988) Development in vitro and pathogenicity of an erythromycin-resistant strain of Renibacterium salmoninarum, the causative agent of bacterial kidney disease in salmonids. Dis Aquat Org 4: $19-25$

Bosnar M, Kelneriç Z, Muniç V, Erakoviç V, Parnham MJ (2005) Cellular uptake and efflux of azithromycin, erythromycin, clarithromycin, telithromycin, and cethromycin. Antimicrob Agents Chemother 49:2372-2377

> Brown LL, Albright LJ, Evelyn TPT (1990) Control of vertical transmission of Renibacterium salmoninarum by injection of antibiotics into maturing female coho salmon Oncorhynchus kisutch. Dis Aquat Org 9:127-131

Bullock GL, Leek SL (1986) Use of erythromycin in reducing vertical transmission of bacterial kidney disease. Vet Hum Toxicol 28:18-20

Calatayud L, Ardanuy C, Cercenado E, Fenoll A and others (2007) Serotypes, clones, and mechanisms of resistance of erythromycin-esistant Streptococcus pneumoniae isolates collected in Spain. Antimicrob Agents Chemother 51: 3240-3246

Clinical and Laboratory Standards Institute (2006) Methods for dilution antimicrobial susceptibility tests for bacteria that grow aerobically. Clinical and Laboratory Standards Institute, Wayne, PA, p M7-A7

Elliott DG, Barila TY (1987) Membrane filtration - fluorescent antibody staining procedure for detecting and quantifying Renibacterium salmoninarum in coelomic fluid of chinook salmon (Oncorhynchus tshawytscha). Can J Fish Aquat Sci 44:206-210

Esposito A, Fabrizi L, Lucchetti D, Marvasi L, Coni E, Guandalini E (2007) Orally administered erythromycin in rainbow trout (Oncorhynchus mykiss): residues in edible tissues and withdrawal time. Antimicrob Agents Chemother 51:1043-1047

- Evelyn TPT, Ketcheson JE, Prosperi-Porta L (1986) Use of erythromycin as a means of preventing vertical transmission of Renibacterium salmoninarum. Dis Aquat Org 2:7-11

> Fairgrieve WT, Masada CL, McAuley WC, Peterson ME, Myers MS, Strom MS (2005) Accumulation and clearance of orally administered erythromycin and its derivative, azithromycin, in juvenile fall Chinook salmon Oncorhynchus tshawytscha. Dis Aquat Org 64:99-106

> Fairgrieve WT, Masada CL, Peterson ME, McAuley WC, McDowell GC, Strom MS (2006) Concentrations of erythromycin and azithromycin in mature Chinook salmon Oncorhynchus tshawytscha after intraperitoneal injection, and in their progeny. Dis Aquat Org 68:227-234

Flagg TA, Mahnaken CVW (1995) An assessment of the status of captive broodstock technology for Pacific salmon. Report No. Project No. 93-56. US Department of Energy, Bonneville Power Administration, Portland, OR

- Franceschi F, Kanyo Z, Sherer EC, Sutcliffe J (2004) Macrolide resistance from the ribosome perspective. Curr Drug Targets Infect Disord 4:177-191

Gaynor M, Mankin AS (2003) Macrolide antibiotics: binding site, mechanism of action, resistance. Curr Top Med Chem 3:949-961

Gilchrist MJ, Greko C, Wallinga DB, Beran GW, Riley DG, Thorne PS (2007) The potential role of concentrated animal feeding operations in infectious disease epidemics and antibiotic resistance. Environ Health Perspect 115: 313-316 
Grayson TH, Alexander SM, Cooper LF, Gilpin ML (2000) Renibacterium salmoninarum isolates from different sources possess two highly conserved copies of the rRNA operon. Antonie Leeuwenhoek 78:51-61

Gutenberger SK, Dale OB, Rohovec JS (1989) In vitro inhibition of Renibacterium salmoninarum by experimental antibiotics. Annual Report 1987, Project No. 83-312, Contract No. DE-A179-83BP11987. US Department of Energy, Bonneville Power Administration, Portland, OR

Hyde TB, Gay K, Stephens DS, Vugia DJ and others (2001) Macrolide resistance among invasive Streptococcus pneumoniae isolates. JAMA 286:1857-1862

Jones RN, Barry AL (1987) Unpredictable influence of human serum on antimicrobial activity of erythromycin and three oxime ether macrolides. Eur J Clin Microbiol Infect Dis 6:81-82

Kirst HA (2002) Introduction to the macrolide antibiotics. In: Schonfeld W, Kirst HA (eds) Macrolide antibiotics. Birkhauser Verlag, Basel, p 1-14

Moffitt CM, Schreck JA (1988) Accumulation and depletion of orally administered erythromycin thiocyanate in tissues of Chinook salmon. Trans Am Fish Soc 117:394-400

National Coordinator for Aquaculture New Animal Drug Applications (2007) Aquaculture drug approval development status. Available at: http://aquanic.org/aquadrugs/ drug \% 20matrices/drug\%20matrices.html

Pascho RJ, Mulcahy D (1987) Enzyme-linked immunosorbent assay for a soluble antigen of Renibacterium salmoninarum, the causative agent of bacterial kidney disease. Can J Fish Aquat Sci 44:183-191

Peters DH, Friedel HA, McTavish D (1992) Azithromycin. A review of its antimicrobial activity, pharmacokinetic properties and clinical efficacy. Drugs 44:750-799

Reinert RR, Wild A, Appelbaum P, Lütticken R, Cil MY, AlLahham A (2003) Ribosomal mutations conferring resistance to macrolides in Streptococcus pneumoniae clinical

Editorial responsibility: David Bruno,

Aberdeen, UK strains isolated in Germany. Antimicrob Agents Chemother 47:2319-2322

Rhodes LD, Grayson TH, Alexander SM, Strom MS (2000) Description and characterization of IS994, a putative IS3 family insertion sequence from the salmon pathogen, Renibacterium salmoninarum. Gene 244:97-107

Roberts MC, Sutcliffe J (2005) Macrolide, lincosamide, streptogramin, ketolide and oxazolidinone resistance. In: White DG, Alekshun MN, McDermott PF (eds) Frontiers in antibiotic resistance: a tribute to Stuart B. Levy. American Society for Microbiology, Washington, DC, p 66-83

Sabath LD, Lorian V, Gerstein D, Loder PB, Finland M (1968) Enhancing effect on alkalinization of the medium on the activity of erythromycin against gram-negative bacteria. Appl Microbiol 16:1288-1292

Shea KM, American Academy of Pediatrics Committee on Environmental Health, American Academy of Pediatrics Committee on Infectious Diseases (2004) Nontherapeutic use of antimicrobial agents in animal agriculture: implications for pediatrics. Pediatrics 114:862-868

Swann MM (1969) Report of the Joint Committee on the use of antibiotics in animal husbandry and veterinary medicine. Her Majesty's Stationary Office, London

Toala P, Wilcox C, Finland M (1970) Effect of $\mathrm{pH}$ of medium and size of inoculum on activity of antibiotics against group D Streptococcus (Enterococcus). Appl Microbiol 19: 629-637

US Fish and Wildlife Service (2005) Fish health for Warm Springs National Fish Hatchery for the Hatchery Review Team. Available at: www.fws.gov/pacific/fisheries/ hatcheryreview/documents/WS--017\%20WarmSprings CHMP FishHealth.pdf

Washington Department of Fish and Wildlife (2002) Hatchery and genetic management plan (HGMP): Skagit spring Chinook fingerling program. Available at: www.wdfw.wa. gov/hat/hgmp/pdf/puget_sound/chinook/marblemount_ fingerling_spring_chinook.pdf

Submitted: January 10, 2008; Accepted: April 25, 2008 Proofs received from author(s): July 17, 2008 